Article

\title{
Nature-Based Solutions Benefit the Economic-Ecological Coordination of Pastoral Areas: An Outstanding Herdsman's Experience in Xilin Gol, China
}

\author{
Boyu Wang ${ }^{1,2}$, Huimin Yan ${ }^{1,2, *}$, Zhichao Xue ${ }^{3}$, Batunacun ${ }^{4}$ (D) and Guihuan Liu 5 \\ 1 Institute of Geographical Sciences and Natural Resources Research, Chinese Academy of Sciences, \\ Beijing 100101, China; wangby.19s@igsnrr.ac.cn \\ 2 University of Chinese Academy of Sciences, Beijing 100049, China \\ 3 School of International Economics and Management, Beijing Technology and Business University, \\ Beijing 100048, China; zhichao.xue@btbu.edu.cn \\ 4 College of Geographical Science, Inner Mongolia Normal University, Hohhot 010022, China; \\ batunacun@zalf.de \\ 5 Chinese Academy for Environment Planning, Beijing 100012, China; liugh@caep.org.cn \\ * Correspondence: yanhm@igsnrr.ac.cn
}

check for

updates

Citation: Wang, B.; Yan, H.; Xue, Z.; Batunacun; Liu, G. Nature-Based Solutions Benefit the EconomicEcological Coordination of Pastoral Areas: An Outstanding Herdsman's Experience in Xilin Gol, China. Land 2022, 11, 107. https://doi.org/ 10.3390/land11010107

Academic Editor: Alexander Khoroshev

Received: 7 December 2021

Accepted: 6 January 2022

Published: 9 January 2022

Publisher's Note: MDPI stays neutral with regard to jurisdictional claims in published maps and institutional affiliations.

Copyright: (C) 2022 by the authors. Licensee MDPI, Basel, Switzerland. This article is an open access article distributed under the terms and conditions of the Creative Commons Attribution (CC BY) license (https:// creativecommons.org/licenses/by/ $4.0 /)$.

\begin{abstract}
Grassland has always had a difficult economic-ecological relationship, as coordination between its ecological conservation and the sustainable development of animal husbandry is required. Nature-based Solutions (NbS), who make full use of the natural ecosystem services, have successfully solved some economic-ecological issues, but still have unclear implementation prospects for grassland management. The Xilin Gol grassland is one of the most typical pastoral areas in China; there is a village chief named Bateer, who has already used NbS for grassland management. To confirm whether the solutions employed by Bateer have been effective for both increasing economic profits and protecting grassland ecosystem, we interviewed him, and many other herdsmen, using questionnaires about their livelihood. Based on these questionnaires, we calculated and compared their income-cost ratios. Meanwhile, we analyzed the NDVI variations inside their rangelands through high-resolution remote sensing images. The results showed that the herdsmen in Bateer's village had a much higher disposable income and income-cost ratio than others, and their rangelands also had a higher value and a more obvious increasing trend of NDVI. Bateer's success proves that the $\mathrm{NbS}$ can also play a positive role in grassland management, which can provide a valuable guidance for economic-ecological coordination in pastoral areas.
\end{abstract}

Keywords: Nature-based Solutions (NbS); economic-ecological coordination; grassland management; ecological conservation; animal husbandry

\section{Introduction}

Animal husbandry is an important part of primary industry, and also the main food source of human society, especially beef and milk, which provide protein, fat and other necessary nutrients to our daily lives [1]. Although the proportions of the secondary and tertiary industries are increasing because of industrialization and urbanization, animal husbandry still owns an important status, especially for those herdsmen for whom animal husbandry is still the only income source available to maintain their normal livelihood. Grassland, occupying about $40 \%$ of the global land surface area, is the material basis of animal husbandry, which determines the production intensity and economic benefit of animal husbandry [2]. The global grassland, however, is now under intensive ecological pressure; around $49 \%$ of grasslands have suffered ecological degradation, which has thus caused a series of ecological and social problems [3,4]. As an important terrestrial ecosystem and biodiversity depository, ecological degradation of grassland will weaken the stability and balance inside the ecosystem, and pose a threat to the survival of many species [5-8]. 
Grassland can also play an important role in mitigating greenhouse gases to support global carbon storage and sequestration, which will be undermined by ecological degradation [9]. Moreover, ecological degradation also reduces the productivity of grassland, which cannot provide strong support for animal husbandry production, thus causing the poverty of herdsmen, and economic stagnation [9-13]. Therefore, preventing ecological degradation and realizing the sustainable development of animal husbandry is always the biggest theme of grassland management, which requires economic-ecological coordination.

Effective management is key to realizing economic-ecological coordination on the grassland, and many countries have proposed a series of different policies and measures to promote the development of animal husbandry, and protect grassland ecosystems. For example, some developed countries have planted a large area of artificial grassland with higher primary productivity and forage yield to replace natural grassland, and have also adopted some high-technology measures, such as automatic feeding and nutritional monitoring systems [14-19]. In addition, European countries such as Switzerland have provided very high financial subsidies for herdsmen to encourage them to keep livestock number within the grassland carrying capacity, and given rewards or punishments according to their performances [20-24]. Other countries, such as the Netherlands and New Zealand, have established a herdsman-enterprise production cooperative, and carried out exclusive training on herdsmen regarding new technologies of grassland management [25-32]. The popularity of artificial grassland and effective supporting measures have brought about the economic-ecological coordination of grassland in such countries.

China has both the largest grassland area and herdsman population in the world; thus, the ecological conservation of grassland and sustainable development of animal husbandry are extremely important in China. To realize economic-ecological coordination, the Chinese government has also proposed a series of policies and measures in pastoral areas, including grassland-livestock balance, house feeding, and banning and delaying grazing to adjust the previous production style, mainly through targeted intervention. So far, however, the economic and ecological effectiveness of such measures have not been obvious, and have faced some controversies [33-37]. For example, as a typical measure of grassland management in China, fencing has always been the main focus of relevant studies, and has aroused many debates. Some believe that fencing can bring a significant improvement of ecological condition and husbandry productivity [38-43], whereas others argue that long-term fencing causes poisonous weeds to expand and encroach on the living spaces of other grass species, thus resulting in biodiversity loss and re-desertification $[44,45]$. Some studies, however, have recently begun to move away from the dispute between traditional and fenced grazing, and explore new ways for grassland management to coordinate economic growth and ecological conservation [46]. Therefore, due to the huge demand for herdsmen's income increase and grassland ecological conservation in the pastoral areas in China, obtaining good economic benefits without destroying grassland ecosystems deserves further exploration.

Nature-based Solutions (NbS), firstly put forward by the World Bank in 2008, and officially defined by the International Union for Conservation of Nature (IUCN) in 2009, have recently become more and more popular due to the shortcomings of human intervention. The NbS advocate to make full use of natural ecosystem services to create natural, social and economic benefits at the same time, and build a human-nature community. The cost is much lower than human intervention, and it has already been successfully put into practice for the issues of climate change and urban ecosystems [47-52]. In 2020, IUCN launched the global standard of $\mathrm{NbS}$, including eight criteria and 28 indicators, with the aim to summarize the achievements of $\mathrm{NbS}$ and avoid some misunderstandings [53]. As for the pastoral areas, however, few studies have so far focused on the $\mathrm{NbS}$ to solve the contradiction between grassland ecological protection and husbandry production $[54,55]$. Fortunately, we became acquainted with an outstanding herdsman named Bateer during our investigation in Xilin Gol in 2019, who emphasized the importance of maximizing the natural power of the grassland ecosystem instead of human high-intensity intervention. 
Taking several new measures of rangeland management and has gathered excellent economic and ecological benefits. He is now well-known in the neighborhood, and greatly influences other herdsmen who have visited him to learn from his experience. We conducted an exclusive interview with Bateer, and found that his unique ideas are a valuable reference for economic-ecological coordination in pastoral areas, and are worthy of further study and discussion.

Therefore, based on the herdsman questionnaires in our investigation, and highresolution remote sensing data, we summarized Bateer's measures and analyzed his and other herdsmen's livelihoods and ecological change characteristics inside the rangelands, to assess the economic and ecological effectiveness of Bateer's measures, compared with other herdsmen's. Thus, we can provide a reference for the $\mathrm{NbS}$ for the future implementation of economic-ecological coordination in the pastoral areas of China.

\section{Materials and Methods}

\subsection{Study Area}

The Xilin Gol League is located in the middle of Inner Mongolia, along the northern border of China. Three main grassland types are all distributed there because of the spatial variations and the moisture conditions. The meadow grassland is in East and West Ujimqin, in the northeast, and the desert grassland is in Erenhot, Sonid Left and Sonid Right, in the west, while the central region with a large area is mainly covered by typical grassland (Figure 1). Furthermore, the vast majority of Xilin Gol is located in the north of China's agropastoral ecotone, and has always been the most active region for nomads and traditional large-scale grazing (Figure 1). In the southern area of Zhenglan and Abaga, near the agropastoral ecotone, however, the husbandry production has shown more characteristics of human intervention under the influence of agricultural civilization. Therefore, Xilin Gol has the most diverse ecological grassland background conditions and, corresponding to husbandry production measures, this makes it an excellent place for relevant studies.

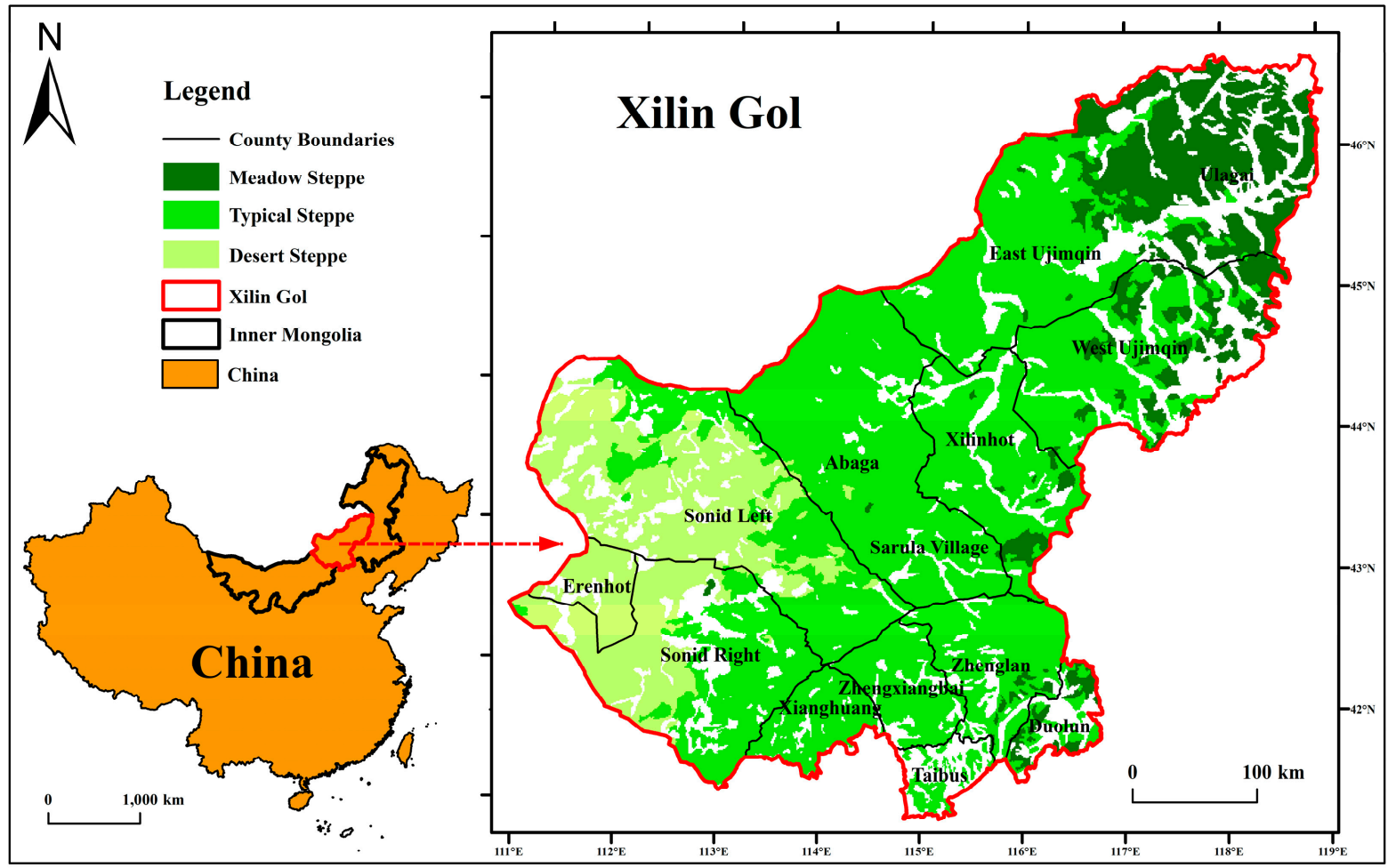

Figure 1. The grassland in Xilin Gol. 
Bateer is an outstanding herdsman, who had his own ideas for grassland ecological conservation and husbandry production. In 1993, he became the chief of the Sarula village in Abaga, where serious grassland degradation and poverty existed at that time because of the constant drought and overgrazing. Facing this dilemma, he made efforts to restore the grassland and increase the herdsmen's income through a series of creative and effective measures. Under his leadership, the poverty in his village has been completely reversed, and the local grassland ecological condition has also been greatly improved. As a result of his legendary experience and huge contribution to local development, he was just awarded a "July 1st Medal", the highest honor of the Communist Party of China.

\subsection{Data Collection}

\subsubsection{Questionnaires}

We interviewed 130 herdsmen in different counties through questionnaires, mainly including the costs of husbandry production and their incomes (Figure 2). In each herdsman's family, we took photos of typical landscapes and production facilities. We kept a detailed record of each questionnaire to summarize the herdsmen's livelihood and current measures they take. As for Bateer, we conducted a long-time interview with him, and carried out a field observation in his rangeland, as well as some other herdsmen in the Sarula village.
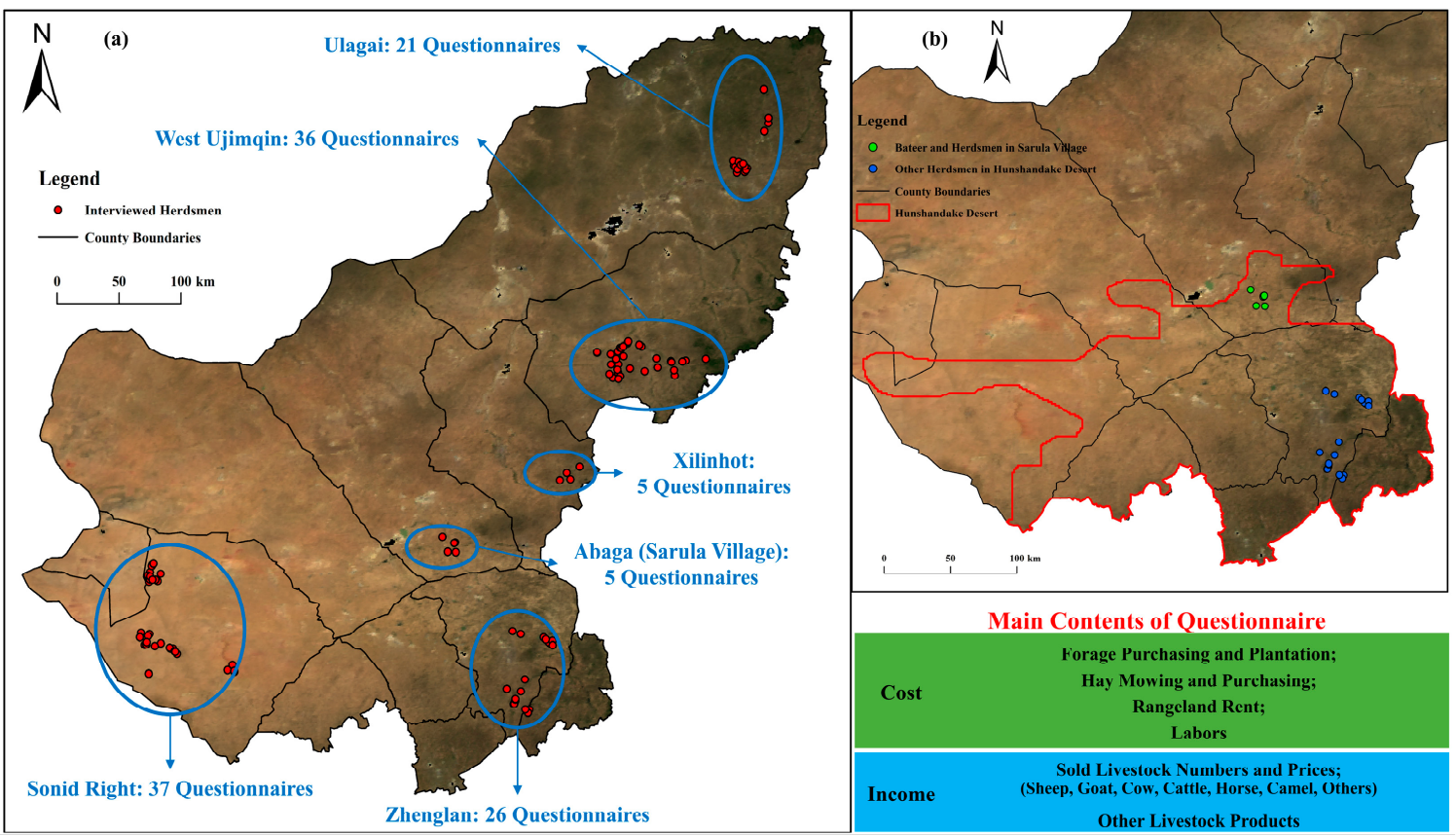

Figure 2. The locations of interviewed herdsmen in (a) Xilin Gol and (b) Hunshandake desert.

\subsubsection{Statistical Yearbook}

To supplement the questionnaire data, we also referred to the Xilin Gol Statistical Yearbook and the Bulletin on husbandry Development, which were launched by the Bureau of Statistics and the Agriculture and Husbandry Bureau of Xilin Gol, to achieve data on livestock numbers, economic growth and the herdsmen's income [56,57].

\subsubsection{Remote Sensing}

The Normalized Difference Vegetation Index (NDVI) is the best indicator of the vegetation coverage, which can effectively reflect the health and stability of the grassland ecosystem [58-60]. In this study, we chose the Sentinel-2 satellite data with a spatial resolution of $10 \mathrm{~m}$, in order to show more detailed information of the land surface and acquire a more accurate result. We selected the images of Xilin Gol in 1993, 1998, 2003, 2008, 2013 
and 2018, to analyze the rangeland ecological changes after Bateer became the chief, and his measures were popularized in Sarula village. For each year, the images from May to August (the time when the grassland has its best ecological condition in the year) were synthesized to calculate the NDVI as the annual vegetation coverage level.

\subsection{Methodology}

\subsubsection{Assessment of Economic Effectiveness of Bateer's Measures}

We evaluated the economic effectiveness based on the "income-cost ratio" in the husbandry production, specifically comparing the annual costs and incomes (financial subsidies not included) of the interviewed herdsmen in different counties. According to our questionnaires, the cost and income of a herdsman family can be calculated as:

$$
\begin{gathered}
C=C_{\text {forage }}+C_{\text {hay }}+C_{\text {rent }}+C_{\text {labor }} \\
I=\sum_{i=1}^{n}\left(L_{i} \times P_{i}\right)+I_{\text {others }}
\end{gathered}
$$

Specifically, $C$ is the total cost of a herdsman family; $C_{\text {forage }}, C_{\text {hay }}, C_{\text {rent }}$ and $C_{\text {labor }}$ represent the cost of forage purchasing and plantation, hay mowing and purchasing, and rangeland rent and labors, respectively. $I$ is the total income of a herdsman family; $i$ represents the livestock type (sheep, goat, cow, cattle, horse, camel, others) and $n$ represents the number of livestock types; $L_{i}$ and $P_{i}$ represent the number and price of the sold livestock type; $I_{\text {others }}$ represents the income from other livestock products.

Then, the "income-cost ratio" was calculated in each herdsman family:

$$
R=I / C
$$

The higher the value, the better economic effectiveness the family had. Therefore, we could judge the economic effectiveness of Bateer's measures by comparing the ratio of the herdsman groups in Sarula village and other regions.

\subsubsection{Assessment of Ecological Effectiveness of Bateer's Measures}

Sarula village is located in the Hunshandake desert, one of the most important ecological conservation areas in the south of Xilin Gol, and the grassland ecological condition within Hunshandake desert is nearly the same. The interviewed herdsmen in Zhenglan were all within this range. Therefore, we compared the NDVI in the rangelands of herdsmen in Sarula village, and others also within the range of the Hunshandake desert, in order to eliminate the uncertainty caused by different geographical background when assessing the ecological effectiveness of Bateer's measures. According to the questionnaire results, we created a 1-km buffer of each herdsman's location as the rangeland, and used it as a mask to extract the NDVI data in ArcGIS. We compared the NDVI of the two groups in 2018, together with the temporal variation slopes from 1993 to 2018, to judge if Bateer's measures had brought a better ecological condition or a significant trend in the rangeland. The slope was calculated with Raster Calculator in ArcGIS, using the following formula:

$$
\text { slope }=\frac{n \sum_{i=1}^{n}\left(i \times N D V I_{i}\right)-\sum_{i=1}^{n} i \sum_{i=1}^{n} N D V I_{i}}{n \sum_{i=1}^{n} i^{2}-\left(\sum_{i=1}^{n} i\right)^{2}}
$$

Specifically, $i$ represents the year $(1993,1998,2003,2008,2013,2018)$ and $n=6 ; N D V I_{i}$ represents the NDVI value of the rangeland in such year. 


\section{Results and Analysis}

\subsection{Bateer's Measures and Comparison with Others}

The grassland-livestock balance is the core of all policies for rangeland management in the pastoral areas of China [61-63] based on which most local herdsmen in Xilin Gol take a series of measures, including banning and delaying grazing, house feeding, and forage plantation, with the aim to adjust the traditional husbandry production pattern. These measures do have some effectiveness in grassland ecological conservation, but they all rely on human intervention, which requires large amounts of labor and financial support. Thus, this reduces the economic benefits of husbandry and increases the burden on herdsmen's lives. Therefore, there is still some uncertainty in coordinating economic growth and ecological conservation.

With the help of the local government, we conducted an exclusive interview with Bateer and summarized his experience. "Hoof Theory" describes the habits and economic benefits of cattle and sheep on grassland, and is the result of Bateer's observations. Specifically, the profit of cattle is five times that of sheep, but they have the same number of hooves treading the grassland. Moreover, the cattle feed with their tongues rolling, while the sheep with their hooves digging. Therefore, the sheep bring more pressure onto grassland ecosystem than the cattle, and offer lower economic benefits. Under the guidance of "Hoof Theory", the number of sheep and goats in Sarula village has been largely reduced, and replaced with high-quality cattle breeds which are less susceptible to disease, and grow faster. Now, the cattle occupy $98 \%$ of the total livestock; therefore, the livestock structure in Sarula village is different from the overall livestock structure in Xilin Gol, in which sheep and goats have the largest proportion (Figure 3a). Meanwhile, the questionnaires showed that the average livestock number in Sarula village was about 50, only one third of the interviewed herdsmen's stock in other counties (Figure 3b).
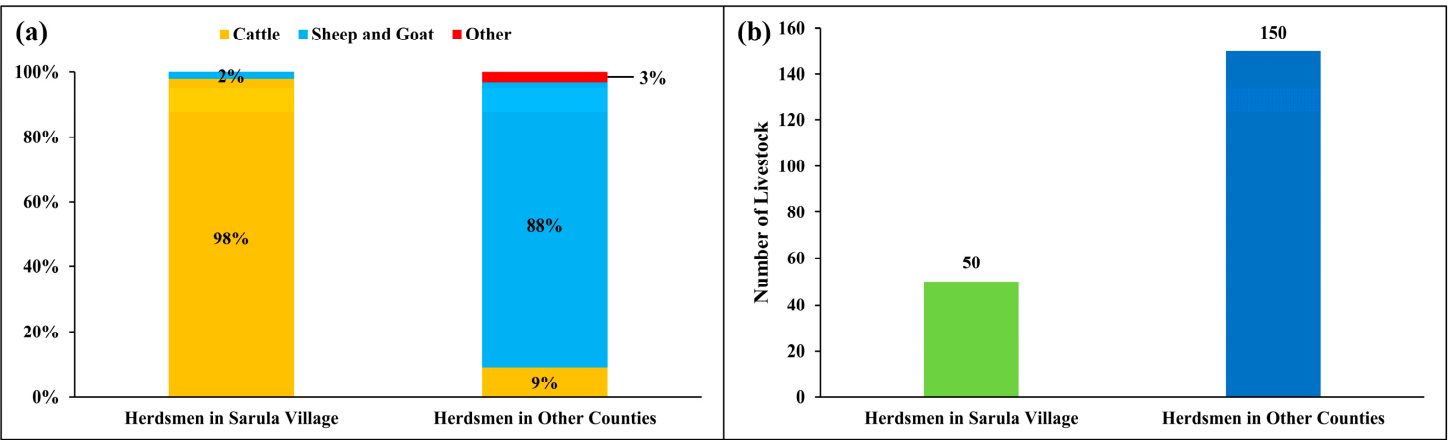

Figure 3. (a) livestock structure and (b) livestock number of Sarula village and other counties.

In addition, Bateer also takes some creative measures:

(1) Paddock grazing. Bateer choses to graze on the premise of grassland-livestock balance, and has adopted paddock grazing through the establishment of fences, to avoid the overuse of any rangeland and make sure that there is enough time for grassland recovery;

(2) Cold-resistance training for livestock. Bateer does not take any special care of livestock in winter, and only gives some aid when severe cold disaster happens, with the aim to promote their ability to survive in the harsh environment;

(3) Hay mowing without home storage. Bateer has adopted a new method to mow the grass where he directly scatters the mowed grass on the rangeland, for livestock to eat, instead of transporting it home for storage.

Bateer provided new ideas for both grassland ecological conservation and husbandry production, which contain his empirical knowledge obtained through long-term observation and practice on the grassland. Bateer's success is because the measures are all based on the theories of ecology and biology, rather than subjective judgements. Moreover, these 
measures are all in line with local herdsmen's lifestyle and husbandry development needs, so there are no obstacles in their implementation (Table 1).

Table 1. The bases and advantages of Bateer's measures.

\begin{tabular}{|c|c|c|}
\hline Bateer's Measures & Bases and Advantages & Corresponding Other Measures \\
\hline Paddock grazing & $\begin{array}{l}\text { There is not too much pressure on any } \\
\text { rangeland for a long time, and the } \\
\text { resilience of the grassland ecosystem } \\
\text { means that it recovers soon after grazing } \\
\text { [64-68]. Grazing is not interrupted to } \\
\text { ensure the sustainable output of } \\
\text { husbandry. }\end{array}$ & Banning and delaying grazing \\
\hline Cold-resistance training for livestock & $\begin{array}{l}\text { Those cold-resistant livestock will } \\
\text { survive without aids in the winter } \\
\text { according to the "survival of the fittest", } \\
\text { and this cold-resistant ability will be } \\
\text { inherited by the offspring and passed on } \\
\text { from generation to generation. }\end{array}$ & Greenhouse and medical aids \\
\hline Hay mowing without home storage & $\begin{array}{c}\text { The livestock can feed easily without } \\
\text { additional disturbance to the grassland } \\
\text { such as trampling and digging } \\
\text { behaviors.Transportation and storage } \\
\text { costs are saved. }\end{array}$ & House feeding and forage plantation \\
\hline
\end{tabular}

\subsection{Assessment of the Effectiveness of Bateer's Measures \\ 3.2.1. Economic Effectiveness}

The income-cost ratio of herdsmen in Sarula village was 3.64, whereas such values in other counties were much lower, meaning that herdsmen in Sarula village could acquire twice or more economic profit than herdsmen in other counties, with nearly the same financial and labor costs under the guidance of Bateer's ideas (Figure 4a). Therefore, the adjustment of livestock structure, and the decrease in livestock number, did not result in economic loss but brought a huge increase in economic benefits. The per capita disposable income of Sarula village had increased from 700 RMB in 1993 to 40000 RMB in 2018, more than three times that of other herdsmen in Xilin Gol, which was undoubtedly an economic miracle [56] (Figure 4b).

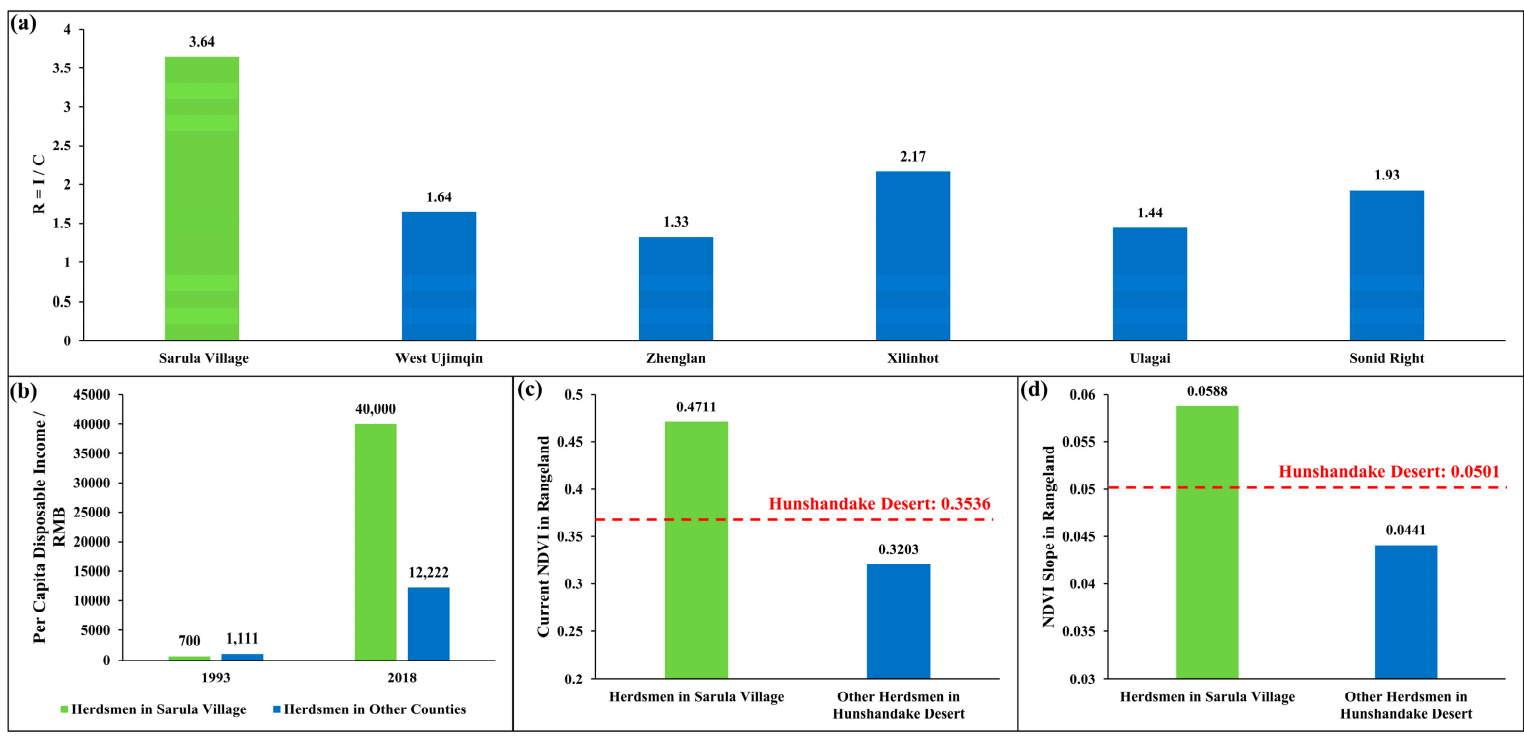

Figure 4. (a) Income-cost ratio; (b) Per capita disposable income; (c) current NDVI; and (d) NDVI slope inside rangelands of herdsmen in Sarula village and other counties. 


\subsubsection{Ecological Effectiveness}

The current NDVI of rangelands of herdsmen in Sarula village is 0.4711 , higher than the overall level in the Hunshandake desert, while that of other herdsmen in the Hunshandake desert is only 0.3203 , reflecting that the overall vegetation coverage inside the rangelands was much better in Sarula village than others (Figures 4c and 5a). As for the NDVI slope, the NDVI inside rangelands of herdsmen in Sarula village showed a significant increasing trend (slope $=0.0588$ ), and a better ecological recovery trend than other herdsmen, and the whole Hunshandake desert (Figures $4 \mathrm{~d}$ and $5 \mathrm{~b}$ ). The results showed that, through paddock grazing and hay mowing without transportation, Bateer has not only effectively maintained the stability of the grassland ecosystem, but also improved it to a condition superior to other grassland of a similar geographical background. This proves that his measures offer huge advantages in ecological conservation.
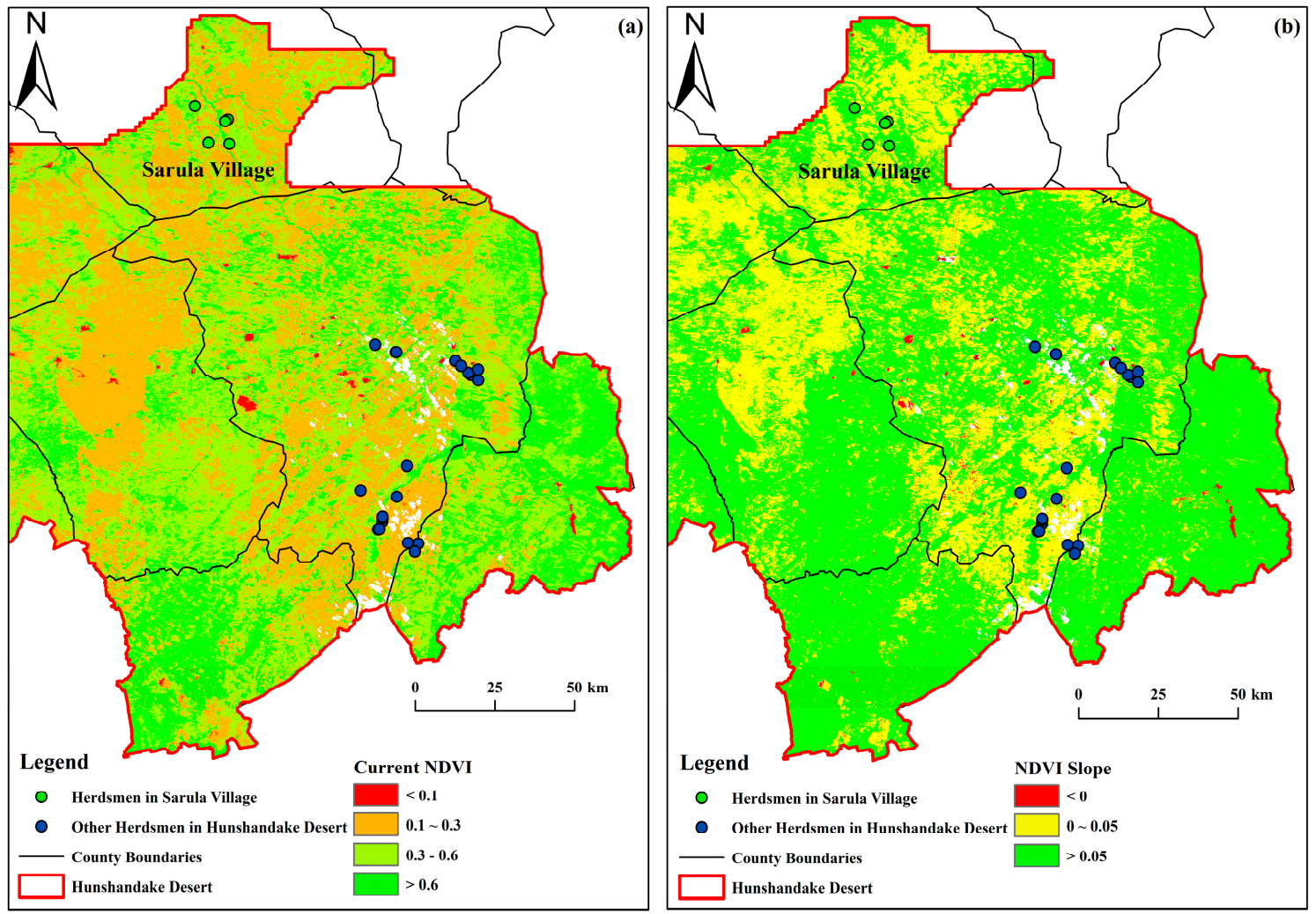

Figure 5. The spatial variations of (a) current NDVI, and (b) NDVI slope inside the rangelands of herdsmen in Sarula village and others in the Hunshandake desert.

\section{Discussion}

\subsection{Adopt the NbS for Future Economic-Ecological Coordination in Pastoral Areas}

Bateer's measures and the current measures represent the $\mathrm{NbS}$, and human intervention, respectively. The implementation of $\mathrm{NbS}$ has obvious advantages to achieve economic-ecological coordination on the grassland. Firstly, the difference between them results from the basic ideology of grassland management (Figure 6). The current measures emphasize human intervention, such as banning and delaying grazing to avoid the overuse of grassland, and limitations on grazing, whereas house feeding, silage corn plantation and livestock breeding improvement reduce the pressure on grassland and maintain husbandry production through targeted adjustments of grazing. Bateer firmly believes that the ideal situation is the harmonious coexistence of all species, including human beings, rather than herdsmen acting as the leader of grassland ecosystem. Therefore, he advocates reducing human intervention and mainly relying on the ecosystem services of grassland itself for ecological restoration and husbandry production, which can obtain the economic benefits of 
husbandry with minimum costs. Although human intervention can also curb the grassland degradation and ensure the continuity of husbandry production, it costs much more than $\mathrm{NbS}$, and once human intervention has been interrupted, it will be difficult to maintain a good ecological condition and animal husbandry productivity.

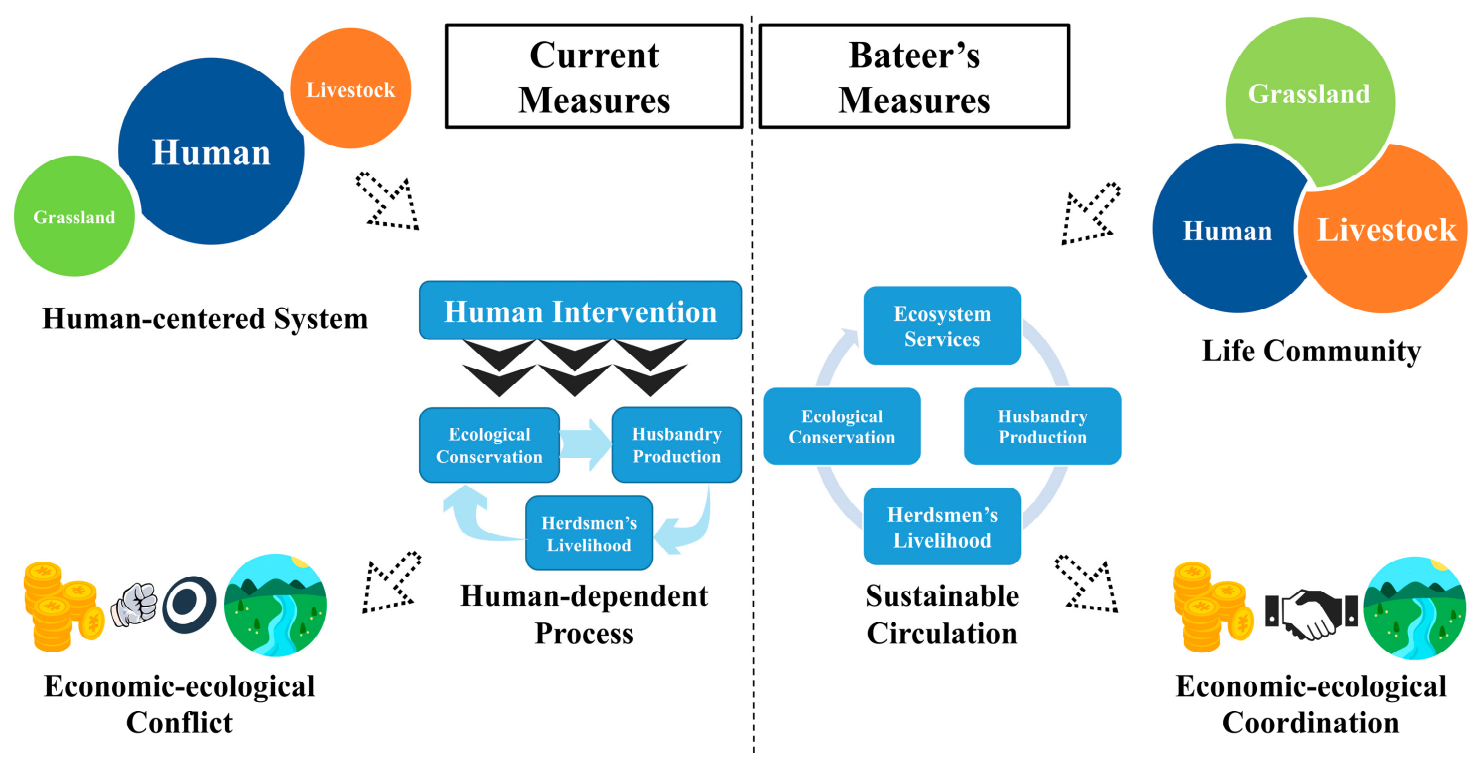

Figure 6. Comparison between human high-intensity intervention (current measures) and the $\mathrm{NbS}$ (Bateer's measures).

Secondly, given the traditional animal husbandry production pattern and herdsmen lifestyle, the NbS may be the most suitable way to realize the economic-ecological coordination on the grassland in China. Specifically, the main pastoral areas in China are all distributed in the northern part, where the nomadic culture has been constantly inherited for thousands of years, especially Xilin Gol. Therefore, most local herdsmen still prefer to insist on grazing rather than extra intervention such as house feeding and artificial grassland, which was proven in our field investigation in Xilin Gol. In comparison, the popularity of artificial grassland and the application of high-technology intervention measures face fewer obstacles in developed countries, such as America, New Zealand and European countries, because there are more advanced economic and technological levels and mature market mechanisms [25-32]. We do not mean that such measures taken by developed countries are not suitable for China; however, presently, the $\mathrm{NbS}$ could be the best choice according to current conditions in the pastoral areas of China, as they are much easier to be approved and accepted by local herdsmen.

To apply NbS more effectively in the grassland pastoral areas, NbS should include two important aspects. Firstly, the grassland ecosystem should be restored mainly based on its own resilience, with the support of suitable policies and measures. Secondly, a life-community of grassland, livestock and human beings should be built, in which human beings are not superior to other species. Moreover, a regional social-ecological system is most resilient when policies and measures are fit for the geographical and social background; the proper human intervention which supports the smooth implementation of $\mathrm{NbS}$ could offer suitable policies and measures for different regions. So, in the future, we should consider the local geographical and social background first, to make sure that $\mathrm{NbS}$ will achieve the desired effect on animal husbandry production and grassland ecological conservation. Furthermore, NbS ultimately have better feasibility and effectiveness because of a high local suitability; therefore, any solution that has had proven success in one region cannot be directly copied into another. Meanwhile, NbS may need timely adjustments in the future to keep pace with the latest conditions of grassland and animal husbandry. Additionally, we must be aware that, $\mathrm{NbS}$ does not mean the abandon of human intervention 
and the adoption of only natural ecosystem services. The essence of $\mathrm{NbS}$ is that the natural ecosystem services play an effective and sustainable role with the help of proper human intervention, which means taking human intervention as a complement to nature, rather than the opposite.

\subsection{Take Advantage of Fences to Support NbS Implementation}

Fences are indispensable and have effectively guaranteed the smooth implementation of Bateer's measures, especially paddock grazing. For the effective application of $\mathrm{NbS}$ on the grassland, fences will play an important and imperative role; they are widespread in the grasslands of many countries and have performed well in ecological conservation and animal husbandry production in many pastoral areas. The establishment of fences has meant successful pasture allocation among herdsmen, and avoided the severe ecological degradation caused by "the Tragedy of the Commons" [69-71]. As for husbandry production, fencing reduces the range of livestock activities and avoids the external interference from wild animals on livestock, so as to greatly improve the efficiency of husbandry production [72-74]. As for ecological conservation, fencing and paddock grazing set aside enough time for grassland self-recovery, significantly improving the stability and productivity of the grassland ecosystem inside the enclosures [38-43]. Bateer has also made full use of fences to support his measures and achieve success.

However, there are also some debates about the negative influence of fences, which we must be aware of and properly deal with, in order to minimize this negative effect and guarantee the effectiveness of $\mathrm{NbS}$. For example, some studies have shown that longterm (older than 8 years) fencing has not brought any ecological and economic benefits, and has even caused some new ecological problems [45]. Specifically, long-term fencing will lead to the rapid growth of weeds, which seriously encroaches on the living space of other species, destroys the original structure of the grassland ecosystem, and reduces biodiversity. Therefore, it is necessary to remove the weeds to avoid hindering the growth of other forage grasses. Long-term fencing also leads to wildlife habitat fragmentation and migration isolation, so the establishment of fences must leave migration corridors for wild animals.

Therefore, the main reason for the negative impact of fencing is the lack of management, not fencing itself. In order to provide powerful support, we recommend that the $\mathrm{NbS}$, as a long-existing grassland management measure, should consider how to use fences properly to achieve the best effectiveness, rather than falling into the dispute between "should use" and "should not use", or traditional and fenced grazing. Necessary management needed to fully utilize the advantages of fences and avoid their adverse effects as far as possible. In addition, the use and purpose of fencing should be fully considered. For example, to separate protected areas or other special areas from pastures, a permanent fixed fence should be used for strict limitation. To separate herdsmen's rangelands, a mobile electric fence should be used for more flexible management, in case of wildlife or livestock migration. Moreover, based on the satellite, UAV and field survey, we can also monitor the temperature, precipitation and grass growth inside the fences, and thus grasp the latest grassland dynamics, and adjust the fences in time.

In summary, the establishment of fences symbolizes the adjustment and optimization of traditional grazing, combining science and technology with nature. Fences will definitely become a very useful tool of $\mathrm{NbS}$ for future grassland ecological conservation and the sustainable development of animal husbandry. Therefore, we must move away from the "traditional or fenced grazing" dispute, and properly make use of fences to make the advantages outweigh the disadvantages, and thus support the $\mathrm{NbS}$ for grassland management in pastoral areas.

\section{Conclusions}

The contradiction between economic growth and grassland ecological conservation needs proper resolution in order to achieve high-quality and sustainable development in 
pastoral areas. Based on the results of the investigation in Xilin Gol, we summarized the experience of Bateer, an outstanding herdsman who has successfully applied $\mathrm{NbS}$ in rangeland management, making full use of the natural ecosystem services to replace unnecessary human intervention, and reducing the labor and financial costs of grassland management. The results showed that, compared with other interviewed herdsmen, such measures taken by Bateer not only protected the grassland ecosystem, but also significantly improved the herdsmen's income and the economic benefits of animal husbandry. That is to say, $\mathrm{NbS}$ (Bateer's measures) are more effective than human high-intensity intervention (current measures) for realizing economic-ecological coordination in pastoral areas. For NbS implementation and economic-ecological coordination in pastoral areas, Bateer's success provides valuable guidance, which can be summarized by the following three points:

1. Maximize the grassland ecosystem services on the basis of ecological conservation;

2. Adopt a "lower number but higher quality" livestock structure to solve the economic-ecological contradiction;

3. Promote the livestock's adaptation to natural disasters, in order to enhance survival ability and reduce the death rate of the livestock.

Author Contributions: Investigation, B.W., H.Y. and Z.X.; writing-original draft preparation, B.W.; writing—review and editing, H.Y. and B.; supervision, H.Y. and G.L.; project administration, H.Y.; funding acquisition, H.Y. All authors have read and agreed to the published version of the manuscript.

Funding: This paper was supported by the Second Tibetan Plateau Scientific Expedition and Research Program (2019QZKK1006), and Strategic Priority Research Program of the Chinese Academy of Sciences (XDA23100202).

Institutional Review Board Statement: Not applicable.

Informed Consent Statement: Not applicable.

Data Availability Statement: The data presented in this study are available on request from the corresponding author.

Acknowledgments: We would like to thank all the experts for their contributions to improving the quality of the paper. And we also want to express our deepest gratitude to the local guide and herders in Xilin Gol, who dedicated time and effort to our fieldwork, especially Bateer who shared his valuable experience with us.

Conflicts of Interest: The authors declare no conflict of interest.

\section{References}

1. Scollan, N.D.; Dewhurst, R.J.; Moloney, A.P.; Murphy, J.J. Improving the quality of products from grassland. In Grassland: A Global Resource; Wageningen Academic Publishers: Wageningen, The Netherlands, 2005; pp. 41-56.

2. Wilsey, B.J. The Biology of Grasslands; Oxford University Press: New York, NY, USA, 2018.

3. Gibbs, H.K.; Salmon, J.M. Mapping the world's degraded lands. Appl. Geogr. 2015, 57, 12-21. [CrossRef]

4. Bardgett, R.D.; Bullock, J.M.; Lavorel, S.; Manning, P.; Schaffner, U.; Ostle, N.; Chomel, M.; Durigan, G.; Fry, E.L.; Johnson, D.; et al. Combatting global grassland degradation. Nat. Rev. Earth Environ. 2021, 2, 720-735. [CrossRef]

5. Ren, Y.J.; Lu, Y.H.; Fu, B.J. Quantifying the impacts of grassland restoration on biodiversity and ecosystem services in China: A meta-analysis. Ecol. Eng. 2016, 95, 542-550. [CrossRef]

6. Dudley, N.; Eufemia, L.; Fleckenstein, M.; Periago, M.E.; Petersen, I.; Timmers, J.F. Grasslands and savannahs in the UN Decade on Ecosystem Restoration. Restor. Ecol. 2020, 28, 1313-1317. [CrossRef]

7. Su, X.K.; Han, W.Y.; Liu, G.H.; Zhang, Y.; Lu, H.T. Substantial gaps between the protection of biodiversity hotspots in alpine grasslands and the effectiveness of protected areas on the Qinghai-Tibetan Plateau, China. Agric. Ecosyst. Environ. 2019, 278, 15-23. [CrossRef]

8. Wang, X.T.; Wang, W.; Liang, C.Z.; Liu, Z.L. Using positive interaction ecology to explain grassland degradation induced by overgrazing. Chin. Sci. Bull. 2015, 60, 2794-2799. [CrossRef]

9. O'Mara, F.P. The role of grasslands in food security and climate change. Ann. Bot. 2012, 110, 1263-1270. [CrossRef] [PubMed]

10. Michalk, D.L.; Kemp, D.R.; Badgery, W.B.; Wu, J.P.; Zhang, Y.J.; Thomassin, P.J. Sustainability and future food security-A global perspective for livestock production. Land Degrad. Dev. 2019, 30, 561-573. [CrossRef]

11. Zhou, Q.; Liu, L.S.; Zhang, Y.L.; Chen, Q.; Zhang, H.F.; Liu, F.G. Effect of Grassland Change on Food Security in Alpine Pastoral Area-A Case Study in Dalag County, China. J. Nat. Resour. 2011, 26, 1333-1345. 
12. Briske, D.D.; Zhao, M.L.; Han, G.D.; Xiu, C.B.; Kemp, D.R.; Willms, W.; Havstad, K.; Kang, L.; Wang, Z.W.; Wu, J.G.; et al. Strategies to alleviate poverty and grassland degradation in Inner Mongolia: Intensification vs production efficiency of livestock systems. J. Environ. Manag. 2015, 152, 177-182. [CrossRef]

13. Liu, S.D.; Zhang, J.J.; Zhang, J.; Li, Z.; Geng, Y.H.; Guo, Y.Q. Assessing Controversial Desertification Prevention Policies in Ecologically Fragile and Deeply Impoverished Areas: A Case Study of Marginal Parts of the Taklimakan Desert, China. Land 2021, 10, 641. [CrossRef]

14. Stuth, J.W.; Lyons, R.K.; Angerer, J.P.; Mckomn, C.D. Role of Nirs-based Nutritional Monitoring Systems for Grazing and Nutritional Management of Range Livestock. In Proceedings of the 2nd Grazing Livestock Nutrition Conference, Steamboat Springs, CO, USA, 2-3 August 1991; Volume 133, pp. 83-93.

15. Caradus, J.; Lovatt, S.; Belgrave, B. Adoption of forage technologies. Proc. N. Z. Grassl. Assoc. 2013, 75, 39-43. [CrossRef]

16. Conner, J.R.; Hamilton, W.T.; Sheehy, D.P.; Stuth, J.W.; Kreuter, U.P. Grassland-based livestock production in temperate zones. World Anim. Rev. 1998, 90, 6-13.

17. Stampa, E.; Zander, K.; Hamm, U. Insights into German Consumers' Perceptions of Virtual Fencing in Grassland-Based Beef and Dairy Systems: Recommendations for Communication. Animals 2020, 10, 2267. [CrossRef] [PubMed]

18. Creighton, P.; Kennedy, E.; Shalloo, L.; Boland, T.M.; Donovan, M.O. A survey analysis of grassland dairy farming in Ireland, investigating grassland management, technology adoption and sward renewal. Grass Forage Sci. 2011, 66, 251-264. [CrossRef]

19. Higgins, S.; Schellberg, J.; Bailey, J.S. Improving productivity and increasing the efficiency of soil nutrient management on grassland farms in the UK and Ireland using precision agriculture technology. Eur. J. Agron. 2019, 106, 67-74. [CrossRef]

20. Barth, L.; Lanz, S.; Hofer, C. Promotion of Grassland-Based Cattle Farming through the 2014-2017 Swiss Agricultural Policy. Agrar. Schweiz 2011, 2, 20-25.

21. Flury, C.; Gotsch, N.; Rieder, P. Site-specific and regionally optimal direct payments for mountain agriculture. Land Use Policy 2005, 22, 207-214. [CrossRef]

22. Odermatt, B.; Keil, N.; Lips, M. Animal Welfare Payments and Veterinary and Insemination Costs for Dairy Cows. Agriculture 2019, 9, 3. [CrossRef]

23. Schulz, T.; Lauber, S.; Herzog, F. Summer Farms in Switzerland: Profitability and Public Financial Support. Mt. Res. Dev. 2018, 38, 14-23. [CrossRef]

24. Schmeller, D.S.; Henry, P.-Y.; Julliard, R.; Gruber, B.; Clobert, J.; Dziock, F.; Lengyel, S.; Nowicki, P.; Déri, E.; Budrys, E.; et al Advantages of Volunteer-Based Biodiversity Monitoring in Europe. Conserv. Biol. 2009, 23, 307-316. [CrossRef]

25. Alagona, P.S. Homes on the range: Cooperative conservation and environmental change on California's privately owned hardwood rangelands. Environ. Hist. 2008, 13, 325-349. [CrossRef]

26. Fernandez-Gimenez, M.E.; Ruyle, G.; McClaran, S.J. An evaluation of Arizona cooperative extension's rangeland monitoring program. Rangel. Ecol. Manag. 2005, 58, 89-98. [CrossRef]

27. van Dijk, W.F.A.; Lokhorst, A.M.; Berendse, F. Factors underlying farmers' intentions to perform unsubsidised agri-environmental measures. Land Use Policy 2016, 59, 207-216. [CrossRef]

28. van Apeldoorn, D.F.; Kok, K.; Sonneveld, M.P.W.; Veldkamp, T. Panarchy Rules: Rethinking Resilience of Agroecosystems, Evidence from Dutch Dairy-Farming. Ecol. Soc. 2011, 16, 39. [CrossRef]

29. Westerink, J.; Melman, D.C.P.; Schrijver, R.A.M. Scale and self-governance in agri-environment schemes: Experiences with two alternative approaches in the Netherlands. J. Environ. Plan. Manag. 2015, 58, 1490-1508. [CrossRef]

30. Ledgard, S.F.; Falconer, S.J.; Abercrombie, R.; Philip, G.; Hill, J.P. Temporal, spatial, and management variability in the carbon footprint of New Zealand milk. J. Dairy Sci. 2020, 103, 1031-1046. [CrossRef]

31. Macdonald, T.O.R.; Rowarth, J.S. Critical success factors when going global: Agribusiness co-operative growth. Proc. N. Z. Grassl. Assoc. 2013, 75, 55-59. [CrossRef]

32. Obrist, R.; Moschitz, H.; Home, R. Reconfiguring the agricultural knowledge system in Switzerland. Agrar. Schweiz 2015, 6 , 220-225.

33. Liu, M.; Dries, L.; Huang, J.K.; Min, S.; Tang, J.J. The impacts of the eco-environmental policy on grassland degradation and livestock production in Inner Mongolia, China: An empirical analysis based on the simultaneous equation model. Land Use Policy 2019, 88, 104167. [CrossRef]

34. Hu, Y.N.; Huang, J.K.; Hou, L.L. Impacts of the Grassland Ecological Compensation Policy on Household Livestock Production in China: An Empirical Study in Inner Mongolia. Ecol. Econ. 2019, 161, 248-256. [CrossRef]

35. Kemp, D.R.; Han, G.D.; Hou, X.Y.; Michalk, D.L.; Hou, F.J.; Wu, J.P.; Zhang, Y.J. Innovative grassland management systems for environmental and livelihood benefits. Proc. Natl. Acad. Sci. USA 2013, 110, 8369-8374. [CrossRef]

36. Li, A.; Gao, L.; Chen, S.; Zhao, J.L.; Ujiyad, S.; Huang, J.H.; Han, X.G.; Bryan, B.A. Financial inclusion may limit sustainable development under economic globalization and climate change. Environ. Res. Lett. 2021, 16, 054049. [CrossRef]

37. Zhang, J.; Brown, C.; Qiao, G.H.; Zhang, B. Effect of Eco-compensation Schemes on Household Income Structures and Herder Satisfaction: Lessons from the Grassland Ecosystem Subsidy and Award Scheme in Inner Mongolia. Ecol. Econ. 2019, 159, 46-53. [CrossRef]

38. Li, Y.Y.; Dong, S.K.; Li, X.Y.; Wen, L. Effect of Grassland Enclosure on Vegetation Composition and Production in Headwater of Yellow River. Acta Agrestia Sin. 2012, 20, 275-279, 286. 
39. Liu, J.K.; Bian, Z.; Zhang, K.B.; Ahmad, B.; Khan, A. Effects of different fencing regimes on community structure of degraded desert grasslands on Mu Us desert, China. Ecol. Evol. 2019, 9, 3367-3377. [CrossRef] [PubMed]

40. Fan, Y.M.; Wu, H.Q.; Sun, Z.J.; Xie, Y.; He, J.; Chai, D.P. Effects of Fencing on the Soil Organic Carbon of Desert Grassland in the Northern Slope of Tianshan. Acta Agrestia Sin. 2014, 22, 65-69.

41. Nakahama, N.; Uchida, K.; Koyama, A.; Iwasaki, T.; Ozeki, M.; Suka, T. Construction of deer fences restores the diversity of butterflies and bumblebees as well as flowering plants in semi-natural grassland. Biodivers. Conserv. 2020, 29, 2201-2215. [CrossRef]

42. Zhai, X.J.; Huang, D.; Wang, K. Effects of Fencing and Grazing on Vegetation and Soil in Typical Grassland. Chin. J. Grassl. 2015, $37,73-78$.

43. Gao, F.; Wang, B.; Shi, Y.X.; Zhang, G.X.; Wang, J.; Si, G.C.; Han, C.H.; Yuan, Y.L.; Hu, Z. The response of alpine grasslands ecosystem in the north Tibet to short-term enclosure. Acta Ecol. Sin. 2017, 37, 4366-4374.

44. Jia, H.T.; Jiang, P.A.; Zhao, C.Y.; Hu, Y.K.; Li, Y. The influence of enclosing life on carbon distribution of grassland ecosystem. Agric. Res. Arid. Areas 2009, 27, 33-36.

45. Sun, J.; Liu, M.; Fu, B.J.; Kemp, D.; Zhao, W.W.; Liu, G.H.; Han, G.D.; Wilkes, A.; Lu, X.Y.; Chen, Y.C.; et al. Reconsidering the efficiency of grazing exclusion using fences on the Tibetan Plateau. Sci. Bull. 2020, 65, 1405-1414. [CrossRef]

46. Liao, C.; Agrawal, A.; Clark, P.E.; Levin, S.A.; Rubenstein, D.I. Landscape sustainability science in the drylands: Mobility, rangelands and livelihoods. Landsc. Ecol. 2020, 35, 2433-2447. [CrossRef]

47. Randrup, T.B.; Buijs, A.; Konijnendijk, C.C.; Wild, T. Moving beyond the nature-based solutions discourse: Introducing naturebased thinking. Urban Ecosyst. 2020, 23, 919-926. [CrossRef]

48. Zhang, X.Q.; Xie, X.; Zeng, N. Nature-based Solutions to address climate change. Progress. Inquisitiones Mutat. Clim. 2020, 16, 336-344.

49. Frantzeskaki, N. Seven lessons for planning nature-based solutions in cities. Environ. Sci. Policy 2019, 93, 101-111. [CrossRef]

50. Kabisch, N.; Frantzeskaki, N.; Pauleit, S.; Naumann, S.; Davis, M.; Artmann, M.; Haase, D.; Knapp, S.; Korn, H.; Stadler, J.; et al. Nature-based solutions to climate change mitigation and adaptation in urban areas: Perspectives on indicators, knowledge gaps, barriers, and opportunities for action. Ecol. Soc. 2016, 21, 39. [CrossRef]

51. Frantzeskaki, N.; McPhearson, T.; Collier, M.J.; Kendal, D.; Bulkeley, H.; Dumitru, A.; Walsh, C.; Noble, K.; Van Wyk, E.; Ordonez, C.; et al. Nature-Based Solutions for Urban Climate Change Adaptation: Linking Science, Policy, and Practice Communities for Evidence-Based Decision-Making. Bioscience 2019, 69, 455-466. [CrossRef]

52. Costa, M.M.; Marchal, R.; Moncoulon, D.; Martin, E.G. A sustainable flywheel: Opportunities from insurance' business to support nature-based solutions for climate adaptation. Environ. Res. Lett. 2020, 15, 111003. [CrossRef]

53. Wang, X.H.; Zhou, J.; Wang, B. The International Experience of Nature-Based Solutions and Its Inspiration for China's Ecological Civilization Construction. Chin. J. Environ. Manag. 2020, 12, $42-47$.

54. Shao, C.L.; Chen, J.Q.; Chu, H.S.; Lafortezza, R.; Dong, G.; Abraha, M.; Batkhishig, O.; John, R.; Ouyang, Z.T.; Zhang, Y.Q.; et al. Grassland productivity and carbon sequestration in Mongolian grasslands: The underlying mechanisms and nomadic implications. Environ. Res. 2017, 159, 124-134. [CrossRef]

55. Wang, L.; Wiesmeier, M.; Zhao, G.Q.; Zhang, R.Y.; Han, G.D.; Siddique, K.H.M.; Hou, F.J. Grazing exclusion-An effective approach for naturally restoring degraded grasslands in Northern China. Land Degrad. Dev. 2018, 29, 4439-4456. [CrossRef]

56. Xilin Gol Municipal Bureau of Statistics. Statistical Yearbook of Xilin Gol League 2016; Xilin Gol Municipal Bureau of Statistics: Xilin Gol, China, 2018.

57. Xilin Gol Municipal Bureau of Statistics. Statistical Bulletin of National Economic and Social Development of Xilin Gol League in 2015; Xilin Gol Municipal Bureau of Statistics: Xilin Gol, China, 2016.

58. Pettorelli, N.; Ryan, S.; Mueller, T.; Bunnefeld, N.; Jędrzejewska, B.; Lima, M.; Kausrud, K. The Normalized Difference Vegetation Index (NDVI): Unforeseen successes in animal ecology. Clim. Res. 2011, 46, 15-27. [CrossRef]

59. Cui, L.L.; Shi, J.; Yang, Y.M.; Fan, W.Y. Ten-day Response of vegetation NDVI to the Variations of Temperature and Precipitation in Eastern China. Acta Geogr. Sin. 2009, 64, 850-860.

60. Wei, Y.X.; Wang, L.W.; Liu, C. Grassland Classification based on MODIS NDVI Time Series Data in Qinghai Province. Resour. Sci. 2008, 30, 688-693.

61. Xu, M.Y. A review of grassland carrying capacity: Perspective and dilemma for research in China on "forage-livestock balance". Acta Prataculturae Sin. 2014, 23, 321-329.

62. Qi, X.H.; Gao, B.; Wang, H.C.; Zhou, J.; Qiao, G.H. The study on the compensation and award standards for forage-livestock balance and grazing prohibition based on herders' perspective of grassland ecological protection subsidies and incentives policies-Take Xilin Gol League as an example. J. Arid Land Resour. Environ. 2016, 30, 30-35.

63. Xu, B.; Yang, X.C.; Jin, Y.X.; Wang, D.L.; Yang, Z.; Li, J.Y.; Liu, H.Q.; Yu, H.D.; Ma, H.L. Monitoring and evaluation of grasslandlivestock balance in pastoral and semi-pastoral counties in China. Geogr. Res. 2012, 31, 1998-2006.

64. Li, Q.F.; Han, G.D.; Ao, T.G.; Wei, Z.J. Effect of different grazing time on vegetation in different paddocks of the rotational grazing rangeland. Chin. J. Ecol. 2004, 23, 7-10.

65. Barnes, M.K.; Norton, B.E.; Maeno, M.; Malechek, J.C. Paddock size and stocking density affect spatial heterogeneity of grazing. Rangel. Ecol. Manag. 2008, 61, 380-388. [CrossRef] 
66. Zhang, J.Y.; Zhao, H.L. An case study on vegetation stability in sandy desertification land: Determination and comparison of the resilience among communities after a short period of extremely aridity disturbance. Acta Ecol. Sin. 2011, 31, 6060-6071.

67. Wang, Z.W. Effect of Stocking Rate on Ecosystem Stability of Stipa Breviflora Desert Steppe; Inner Mongolia Agricultural University: Hohhot, China, 2009.

68. Dong, S.K.; Wen, L.; Liu, S.L.; Zhang, X.F.; Lassoie, J.P.; Yi, S.L.; Li, X.Y.; Li, J.P.; Li, Y.Y. Vulnerability of Worldwide Pastoralism to Global Changes and Interdisciplinary Strategies for Sustainable Pastoralism. Ecol. Soc. 2011, 16, 10. [CrossRef]

69. Yundannima, Y.N. Rangeland Use Rights Privatisation Based on the Tragedy of the Commons: A Case Study from Tibet. Conserv. Soc. 2017, 15, 270-279.

70. Brekke, K.A.; Oksendal, B.; Stenseth, N.C. The effect of climate variations on the dynamics of pasture-livestock interactions under cooperative and noncooperative management. Proc. Natl. Acad. Sci. USA 2007, 104, 14730-14734. [CrossRef]

71. Sun, Z.B.; Sun, Q.L.; Song, L.J.; Miao, Y.J. Research on the Strategic Choice of Herdsmens Behavior in Grassland Resources Protection. Acta Agrestia Sin. 2012, 20, 805-811.

72. You, Z.Q.; Jiang, Z.G.; Li, C.W.; Mallon, D. Impacts of grassland fence on the behavior and habitat area of the critically endangered Przewalski's gazelle around the Qinghai Lake. Chin. Sci. Bull. 2013, 58, 2262-2268. [CrossRef]

73. Zhang, L.; Liu, J.Z.; Wang, D.J.; Wang, H.; Wu, Y.L.; Lu, Z. Fencing for conservation? The impacts of fencing on grasslands and the endangered Przewalski's gazelle on the Tibetan Plateau. Sci. China Life Sci. 2018, 61, 1593-1595. [CrossRef]

74. Poor, E.E.; Jakes, A.; Loucks, C.; Suitor, M. Modeling Fence Location and Density at a Regional Scale for Use in Wildlife Management. PLoS ONE 2014, 9, e83912. [CrossRef] 